\title{
Detection of autoantibodies against glycosylated-DNA in diabetic subjects: Its possible correlation with $\mathrm{HbA}_{1 C}$
}

\author{
Jamal Ahmad ${ }^{\mathrm{a}, *}$, Anuj Gupta ${ }^{\mathrm{b}}$, Khursheed Alam ${ }^{\mathrm{c}}$ and Khalid Jamal Farooqui ${ }^{\mathrm{a}}$ \\ ${ }^{a}$ Centre for Diabetes and Endocrinology, Jawaharlal Nehru Medical College, Aligarh Muslim University, Aligarh, \\ U.P., India \\ ${ }^{\mathrm{b}}$ Department of Medicine, Jawaharlal Nehru Medical College, Aligarh Muslim University, Aligarh, U.P., India \\ ${ }^{\mathrm{c}}$ Department of Biochemistry, Jawaharlal Nehru Medical College, Aligarh Muslim University, Aligarh, U.P., India
}

\begin{abstract}
Aims: The vascular tissues have a long memory of their previous glycemic control and intervention studies have demonstrated that microvascular complications are highly correlated with mean glycemic control as measured by glycolated hemoglobin $\mathrm{A}_{1} \mathrm{C}\left(\mathrm{HbA}_{1} \mathrm{c}\right)$. The present study was carried out to evaluate the autoantibodies against glycosylated DNA (DNAAGEs) in diabetic sera to see if the level of HbAlc has correlation with the activity of DNA-AGEs, another marker of chronic glycemia.

Methods: Glucose-6-phosphate induced glycosylation of native DNA was studied in 150 diabetic sera (T1DM = 9, T2DM $=141$ ) by spectroscopic techniques (UV and fluorescence) and agarose gel electrophoresis. Direct binding and inhibition enzyme immunoassays were carried out to evaluate binding and specificity of anti-glycated-DNA autoantibodies (anti-DNA-AGE autoantibodies) in sera of diabetes patients. A quantitative estimation of $\mathrm{HbA}_{1 c}$ was carried out in normal and diabetes sera. Results: Anti-DNA-AGEs autoantibodies in 55\% of diabetic sera (85/150) showed more binding with glycated-DNA compared to native DNA which was subjected to inhibition ELISA indicating true interaction of these autoantibodies in diabetes with glycated DNA. Higher binding with glycosylated-DNA against native-DNA was observed in subjects with HbA1c of $9.8 \pm 3.3 \%$ compared to those with HbA1c of $7.7 \pm 1.7 \%(p<0.001)$. Linear correlation analysis showed that mean absorbance difference was significantly related to HbA1c $(r=0.486, p<0.001)$, nephropathy $(r=0.239, p<0.003)$, retinopathy $(r=0.165, p<$ $0.05)$.

Conclusions: Autoantibodies against glycosylated DNA were correlated with $\mathrm{HbA}_{1} \mathrm{c}$ and microvascular complications and may be useful as another biomarker for assessment of chronic glycemia.
\end{abstract}

Keywords: Autoantibodies, glycosylated-DNA, diabetes mellitus

\section{Introduction}

Reducing sugars react non-enzymatically with amino groups in proteins, lipids, and nucleic acids through a series of reactions forming Schiff base and Amadori product to produce AGEs - advance glycation end products [1-3]. Some of these factors that influence protein glycation also contribute to the non-enzymatic glyca-

*Corresponding author. Tel.: +91 571 2721544; Fax: +91 571 2721544; E-mail: jamalahmad11@rediffmail.com. tion of DNA nucleobases and nucleosides [4,5]. In the cell, glucose has the slowest rate of glycation, mostly phosphorylaed to glucose-6-phosphate (G16-P) that is more relevant DNA-AGE- precursor forms AGEs at a faster rate [6]. Many AGEs fluoresce under ultraviolet light and some are capable of intra- and intermolecular cross linking [7]. The formation of DNA-AGEs is not only limited to reactions of isolated DNA in-vitro, but also takes place under cell culture conditions, invivo. The carboxyethylatedguanine $(\mathrm{CEdG})$ has been reported to be detected in healthy human urine [8] and 
also in the genomic DNA of human smooth muscle cells and bovine aorta endothelium cells in-vitro [9]. Thus, CEdG is the only DNA-AGE to be detected in vivo, however, information on the nuclear concentration of sugar and sugar degradation product is rare. In the nucleus, DNA itself may be considered as an important carbonyl precursor. The oxidation reaction releases sugar degradation products from the DNA backbone, which then, in reverse, may directly glycate the DNA [10]. The presence of nucleotide AGEs in DNA is also associated with increased mutation frequency, DNA strand breaks and cytotoxicity [11]. The AGEs formed during the glycation of DNA/ protein possess unique epitopes capable of triggering an autoimmune response [12], and AGEs autoantibodies have also been reported in the sera of diabetic patients [13]. A casual relationship between chronic hyperglycemia and diabetic microvascular disease, long inferred from clinical studies, has now been definitely established by data from the Diabetic Control and Complications Trial [14], the United Kingdom Prospective Diabetes Study [15], the Kumamoto Study [16], and HbA1c is considered to be the gold standard for assessment of chronic glycemia. New biochemical markers related to AGEs have also been described, however, the predictive value of a single marker and combinations of markers need to be tested in long term clinical Studies [17]. Furthermore, role of AGEs in microvascular complications has been clearly defined and thus AGEs may prove authentic marker for assessment of microvascular complications in diabetes [18-21].

In the present study, we investigated the presence of anti-glycated-DNA autoantibodies (anti-DNA-AGE autoantibodies) in diabetes sera, its correlation with $\mathrm{HbA}_{1} \mathrm{c}$ and microvascular complications. An attempt was also made to evaluate, if DNA-AGEs emerge as additional biomarker for assessment of chronic glycemia in diabetes.

\section{Patients and methods}

The study was conducted at the Centre for Diabetes and Endocrinology and Department of Biochemistry, J.N. Medical College, Aligarh Muslim University, Aligarh (India). Blood samples from 150 diabetic patients (64 males and 86 females; 9 cases of Type 1 and 141 cases of Type2) were collected in a fasting state after an overnight fast of 10-12 hrs. Fasting blood ( $n=$ 45) from apparently healthy, age- and sex-matched, individuals were also collected and served as controls.
An informed consent was obtained from each subject at the time of enrollment and clearance was obtained from the Institutional Ethics Committee.

A detailed history and physical examination was carried out for each subject. Age, sex, anthropometric measurements (body mass index), duration of diabetes, history of smoking, glycemic control at the time of participation in the study, lipid profile, presence of retinopathy, nephropathy (creatinine $>1.5 \mathrm{mg} \%$ or presence of micro- or macroalbuminuria), neuropathy (absence of perception of the Semmes-Weinstain monofilament at 2 of 10 standard plantar sites on either foot), peripheral vascular disease (ischemic symptoms and intermittent claudication of rest pain, with or without absence of pedal pulses or posterior tibial pulses) and hypertension were noted in every patient. Patients were diagnosed as having cardiovascular disease on the basis of history of angina, previous myocardial infarction, coronary artery bypass graft or balloon angioplasty, ECG changes and echocardiography.

\subsection{Glycation of DNA}

Commercially available native DNA (purified from calf thymus) was purchased from Sigma Chemical Company, USA (product no D-1501 "DNA Sodium salt" type 1 , highly polymerized). Pilot experiments were carried out with different concentrations of native DNA $(10-100 \mu \mathrm{g} / \mathrm{ml})$ and a fixed concentration of Gl 6-P to decide the optimum concentration of DNA to be taken for generation of advanced glycation end products. Glycation of native DNA was carried out in vitro. Native DNA $(10 \mu \mathrm{g} / \mathrm{ml})$ was incubated at $37^{\circ} \mathrm{C}$ with a fixed amount of Gl 6-P $(130 \mathrm{mM} / \mathrm{ml})$ in phosphate buffer (0.2 M, pH 7.4) for 3,7,10 and 14 days. Controls were devoid of glucose-6-phosphate. We have chosen $130 \mathrm{mM}$ Gl 6-P to glycate the native DNA because (i) potency of Gl 6-P as a glycating agent is larger than that of glucose, as suggested by previous workers [22] (ii) the above concentration of Gl 6-P has previously been shown to correspond to the minimum concentration for an in vitro glycation of proteins, DNA etc. [23-25]. Structural changes in glycated DNA were investigated by following techniques.

\subsection{Spectroscopic (UV \& fluorescence) studies on glycated-DNA}

Absorption profile of native DNA and its glycated counterparts were recorded in the wavelength range of 200-400 nm using quartz cuvette of $1 \mathrm{~cm}$ path 
length. Fluorescence emission spectra of native DNA and glycated-DNA samples were also recorded. Equal amounts of native- and glycated-DNA samples were excited at $370 \mathrm{~nm}$ and emission profile was recorded.

\subsection{Agarose gel electrophoresis}

Nuclease free agarose $(0.6 \%)$ was dissolved in electrophoresis buffer (40 mM Tris-acetate, $\mathrm{pH} 8.0$ containing 2 mM EDTA) and poured in a comb fitted transparent plastic tray. The molten agarose was allowed to solidify at room temperature. Comb was carefully removed and equal amounts of native and glycated-DNA samples (pre-mixed with tracking dye) were loaded in separate wells. Electrophoresis was carried out for $2 \mathrm{~h}$ at $30 \mathrm{~mA}$ constant current. The gel was then stained with ethidium bromide $(0.5 \mu \mathrm{g} / \mathrm{ml}$ distilled water $)$ and bands were visualized under UV light.

\subsection{Enzyme linked immunosorbent assay (ELISA)}

ELISA was carried out on flat bottom polystyrene maxisorp modules as described elsewhere [26]. Briefly, microtitre wells were filled with $100 \mu \mathrm{l}$ of native/ glycated-DNA antigens $(2.5 \mu \mathrm{g} / \mathrm{ml})$ in TBS buffer (10 mM Tris, pH 9.6 containing $150 \mathrm{mM} \mathrm{NaCl}$ ) and incubated for $2 \mathrm{~h}$ at $37^{\circ} \mathrm{C}$ and overnight at $4^{\circ} \mathrm{C}$. Each sample was coated in duplicate and half of the wells served as control devoid of antigen coating. Unbound antigens were washed thrice with TBS-T (TBS buffer containing $0.05 \%$ Tween-20) and unoccupied sites were blocked with $150 \mu \mathrm{l}$ of $2 \%$ fat free milk (dissolved in TBS buffer) for $4-6 \mathrm{~h}$ at $37^{\circ} \mathrm{C}$. At the end of incubation, wells were washed four times with TBS-T. Sera derived from normal human and diabetes patients were serially diluted (starting from 1:100 dilutions) in TBS-T and added to antigen coated wells (100 $\mu \mathrm{l} /$ well). Antigen-antibody interaction was allowed for $2 \mathrm{~h}$ at $37^{\circ} \mathrm{C}$ and overnight at $4^{\circ} \mathrm{C}$. Bound antibodies were assayed with anti-human IgG alkaline phosphatase conjugate using p-nitrophenyl phosphate as substrate. The absorbance (A) of each well was monitored at $410 \mathrm{~nm}$ on an automatic microplate reader. Each sample was run in duplicate. Results were expressed as a mean of $\mathrm{A}_{\text {test }}-\mathrm{A}_{\text {control }}$.

\subsection{Inhibition ELISA}

The antigenic specificity of autoantibodies in diabetes sera was determined by inhibition ELISA. Varying amount of inhibitors $(0-10 \mu \mathrm{g} / \mathrm{ml})$ was mixed with fixed amount of $100 \mu \mathrm{l}$ of 1:100 diluted sera of selected diabetic cases. The mixture was incubated at room temperature for $2 \mathrm{~h}$ and overnight at $4{ }^{\circ} \mathrm{C}$ and added in the wells instead of serum. The remaining steps were the same as in direct binding ELISA. Percent inhibition was calculated using the formula:

$$
\text { Percent inhibition }=-\frac{A_{\text {inhibited }}}{A_{\text {uninhibited }}} \times 100
$$

where, $A_{\text {inhibited }}$ and $A_{\text {uninhibited }}$ stand for microtitre wells' absorbance in presence and absence of inhibitor.

\subsection{Estimation of $\mathrm{HbA}_{1 \mathrm{C}}$}

Kit(s) purchased from of Bio-Rad (USA) was used for the estimation of $\mathrm{HbA}_{1 c}$ in diabetes sera using HPLC based D-10 $\mathrm{HbA}_{1 c}$ program. In this procedure, sample is automatically diluted and injected into the analytical cartridge. The D-10 device delivers buffer gradient of increasing ionic strength to the cartridge, and the hemoglobins are separated on the basis of their interaction(s) with the cartridge material. The separated hemoglobins pass through the flow cell of the photometer and the absorbance is recorded at $415 \mathrm{~nm}$. The software performs reduction of raw data collected from each analysis. Two-level calibration is used for quantitation of $\mathrm{HbA}_{1 c}$ values. A sample report and chromatogram is generated for each sample. The $\mathrm{HbA}_{1 c}$ area is calculated using an exponentially modified Gaussian (EMG) algorithm that excludes the labile $\mathrm{A}_{1 c}$ and carbamylated peak area from the $\mathrm{A}_{1 c}$ peak area. The normal $\mathrm{HbA}_{1 c}$ reference range of the kit used in this study was $4.27-6.07 \%$.

\subsection{Statistical analysis}

Results are expressed as mean \pm SEM. All statistical calculations were performed using SPSS software (version 16). A $p$ values of $<0.05$ was considered as statistically significant. Linear correlation analysis using absorbance difference as dependent variables was also performed. 
Table 1

Demographic profile and clinical characteristics of diabetic subjects

\begin{tabular}{|c|c|c|c|c|c|c|c|}
\hline \multirow[t]{2}{*}{ No. } & \multirow[t]{2}{*}{ Variables } & \multicolumn{2}{|c|}{ Total } & \multicolumn{2}{|c|}{ Male } & \multicolumn{2}{|c|}{ Female } \\
\hline & & Mean & S.D. & Mean & S.D. & Mean & S.D. \\
\hline 1 & Age (years) & 50.5 & 11.5 & 53.0 & 12.5 & 48.5 & 10.0 \\
\hline 2 & Body mass index $\left(\mathrm{kg} / \mathrm{m}^{2}\right)$ & 25.5 & 5.6 & 24.4 & 6.4 & 26.3 & 4.8 \\
\hline 3 & W.C. $(\mathrm{cm})$ & 93.2 & 10.9 & 94.6 & 12.0 & 92.2 & 9.8 \\
\hline 4 & H.C. $(\mathrm{cm})$ & 95.8 & 9.7 & 95.6 & 10.2 & 96.0 & 9.4 \\
\hline 5 & Waist: hip ratio & 0.97 & 0.06 & 0.98 & 0.06 & 0.96 & 0.06 \\
\hline 6 & Duration of diabetes (years) & 7.0 & 5.0 & 6.5 & 4.5 & 7.0 & 5.0 \\
\hline \multirow[t]{2}{*}{7} & Blood sugar (mg\%), Fasting & 138.0 & 53.0 & 139.0 & 61.0 & 136.0 & 47.0 \\
\hline & Post prandial & 180.0 & 68.0 & 183.0 & 72.0 & 177.0 & 65.0 \\
\hline 8 & $\mathrm{HbA}_{1 c}(\%)$ & 8.8 & 2.9 & 9.1 & 3.3 & 8.6 & 2.6 \\
\hline 9 & S. creatinine $(\mathrm{mg} \%)$ & 1.0 & 0.3 & 1.1 & 0.4 & 1.0 & 0.3 \\
\hline 10 & Total cholesterol (mg/dl) & 183.0 & 43.0 & 178.0 & 40.0 & 186.0 & 44.0 \\
\hline 11 & LDL-cholesterol (mg/dl) & 102.0 & 30.0 & 102.0 & 29.0 & 103.0 & 30.0 \\
\hline 12 & Triglycerides (mg/dl) & 132.0 & 46.0 & 130.0 & 42.0 & 133.0 & 49.0 \\
\hline 13 & HDL-cholesterol (mg/dl) & 44.0 & 7.0 & 44.0 & 7.0 & 45.0 & 7.0 \\
\hline 14 & VLDL-cholesterol (mg/dl) & 30.0 & 13.0 & 29.0 & 14.0 & 31.0 & 17.0 \\
\hline 15 & Systolic B.P. (mmHg) & 138.0 & 18.0 & 139.0 & 18.0 & 137.0 & 17.0 \\
\hline 16 & Diastolic B.P. (mmHg) & 87.0 & 11.0 & 87.0 & 11.0 & 86.0 & 11.0 \\
\hline
\end{tabular}

Table 2

Application of "t" test on various glycemic parameters and disease duration

\begin{tabular}{|c|c|c|c|c|c|c|}
\hline \multirow[t]{2}{*}{ Variable } & \multicolumn{2}{|c|}{ Value with native DNA } & \multicolumn{2}{|c|}{ Value with DNA-AGEs } & \multirow[t]{2}{*}{$\mathrm{t}^{*}$} & \multirow[t]{2}{*}{$\mathrm{p}^{* *}$} \\
\hline & Mean & S.D. & Mean & S.D. & & \\
\hline Fasting blood sugar (mg/dl) & 120.0 & 36.0 & 151.0 & 60.0 & -2.60 & $<0.011$ \\
\hline Post prandial blood sugar $(\mathrm{mg} / \mathrm{dl})$ & 155.0 & 50.0 & 199.0 & 74.0 & -3.15 & $<0.002$ \\
\hline $\mathrm{HbA}_{1 c}(\%)$ & 7.6 & 1.7 & 9.8 & 3.3 & -3.70 & $<0.001$ \\
\hline Disease duration (years) & 7.0 & 5.5 & 6.5 & 5.0 & 0.78 & $>0.437$ \\
\hline
\end{tabular}

$t$ * is the value of student's ' $t$ ' test.

$\mathrm{p}^{* *}$ indicate difference (independent sample ' $\mathrm{t}$ ' test).

\section{Results}

The demographic and clinical characteristics of 150 diabetic subjects included in the study are shown in Table 1. The mean age of diabetic subjects was $50.5 \pm$ 11.5 years. Females predominated $(85 \%)$. Majority of the subjects $(141 / 150,94 \%)$ had Type 2 DM. The mean duration of diabetes was $7.0 \pm 5.0$ years. Forty two patients $(28 \%)$ had retinopathy, $14(9.3 \%)$ neuropathy, $50(33.3 \%)$ nephropathy, $24(16 \%)$ coronary artery disease, $2(1.3 \%)$ peripheral vascular disease and 51 (34\%) were hypertensive.

Table 2 shows the glycemic parameters in diabetic subjects on the basis of relative absorption to native DNA and DNA-AGEs. There was significant difference on the basis of fasting $\&$ post prandial blood sugar and $\mathrm{HbA}_{1 c}(p<0.011, p<0.002, p<0.001$ respectively) but no significant difference on the basis of disease duration.

\subsection{Characterization of glycated-DNA}

Native DNA $(10 \mu \mathrm{g} / \mathrm{ml})$ was mixed with $130 \mathrm{mM}$ of Gl 6-P and incubated for 3,7,10 and 14 days and then subjected to spectrophotometric analysis (Fig. 1). Native DNA showed the characteristic peak at $260 \mathrm{~nm}$. Upon glycation, the absorbance values corresponding to $260 \mathrm{~nm}$ showed hyperchromicity. Compared to 260 nm peak of native DNA, the hyperchromicities shown by $3,7,10$ and 14 days old glycated-DNA samples were $74.8 \%, 80.7 \%, 81.6 \% \& 88.1 \%$ respectively. The findings suggest structural perturbations in DNA as a consequence of Gl 6-P mediated glycation.

Possible generation of fluorogenic AGEs in glycatedDNA samples were detected using excitation wavelength $\left(\lambda_{e x}\right)$ of $370 \mathrm{~nm}$ [27]. Under identical conditions, native DNA did not show any fluorescence intensity. However, glycated-DNA samples showed maximum fluorescence emission intensity around 430 nm which increased with incubation time (Fig. 2). The results indicate time dependent generation of fluorophores in DNA samples treated with glucose.

Equal amounts of native and glycated-DNA samples were subjected to agarose gel electrophoresis. The migration pattern of ethidium bromide stained bands has been shown in Fig. 3. The pattern shown by native DNA is typical of genomic DNA (lane 1). The 


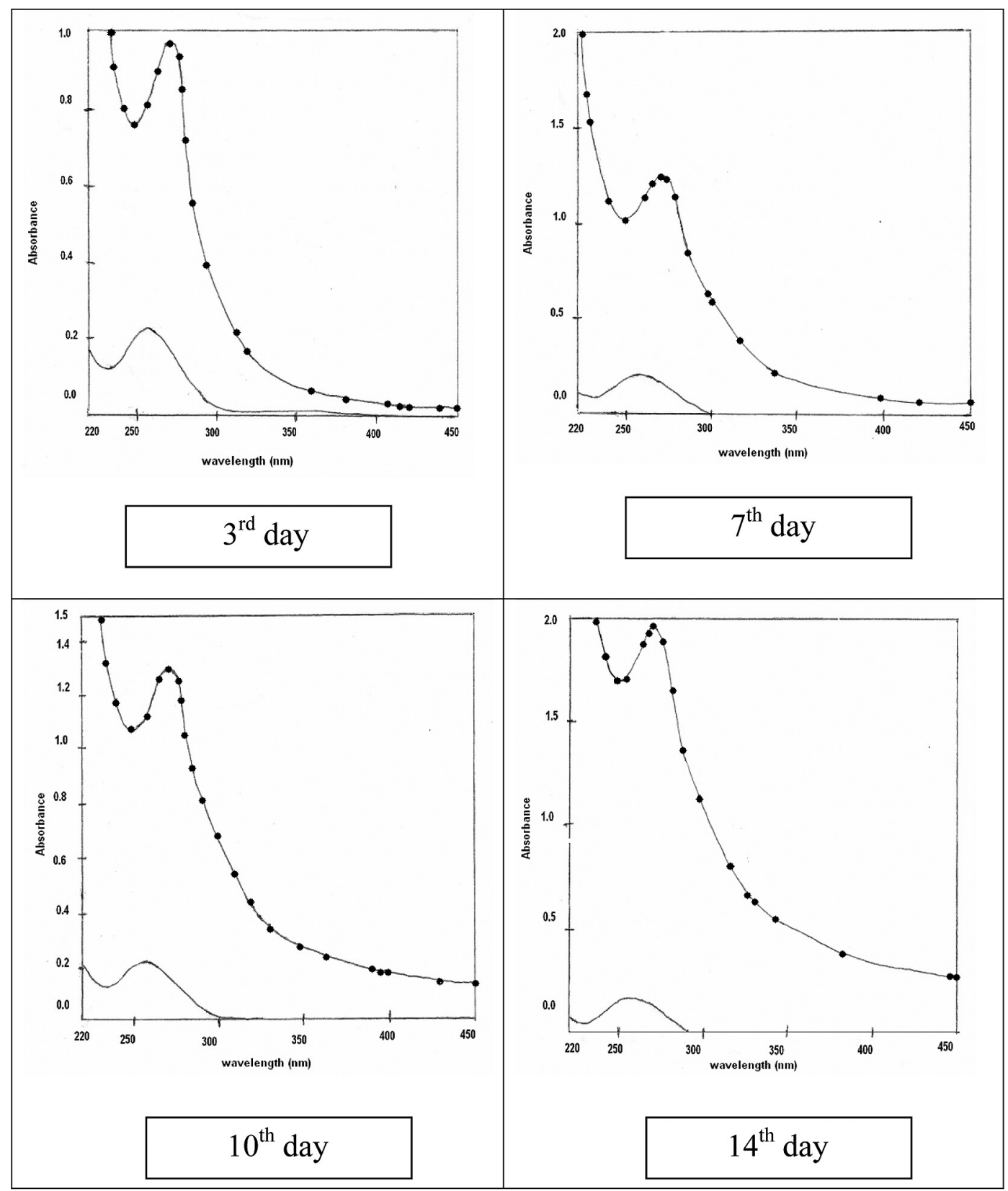

Fig. 1. Absorption profile of native DNA (-) incubated with Gl 6-P for 3,7,10 and 14 days ( $\bullet-\bullet)$.

ethidium assisted fluorescence of glycated-DNA samples were found to be decreasing with increasing incubation time (lanes 2-5). Furthermore, faster mobility of glycated-DNA samples were also observed. It may be due to generation of single strand breaks by glycation induced reactive intermediates. Furthermore, the heavily glycated-DNA sample (lane 5) migrated as a short stretch (or band) of lower intensity. The results reiterate $\mathrm{Gl}$ 6-P induced modifications.

\subsection{Detection of anti-glycated-DNA autoantibodies (anti-DNA-AGEs autoantibodies) in type 2 diabetes sera by ELISA}

Anti-glycated-DNA autoantibodies in diabetes sera were detected by enzyme immunoassay on microtitre wells coated with native- and two week old glycatedDNA. Binding profile of diabetes sera with native and glycated-DNA antigens has been shown in Fig. 4. 


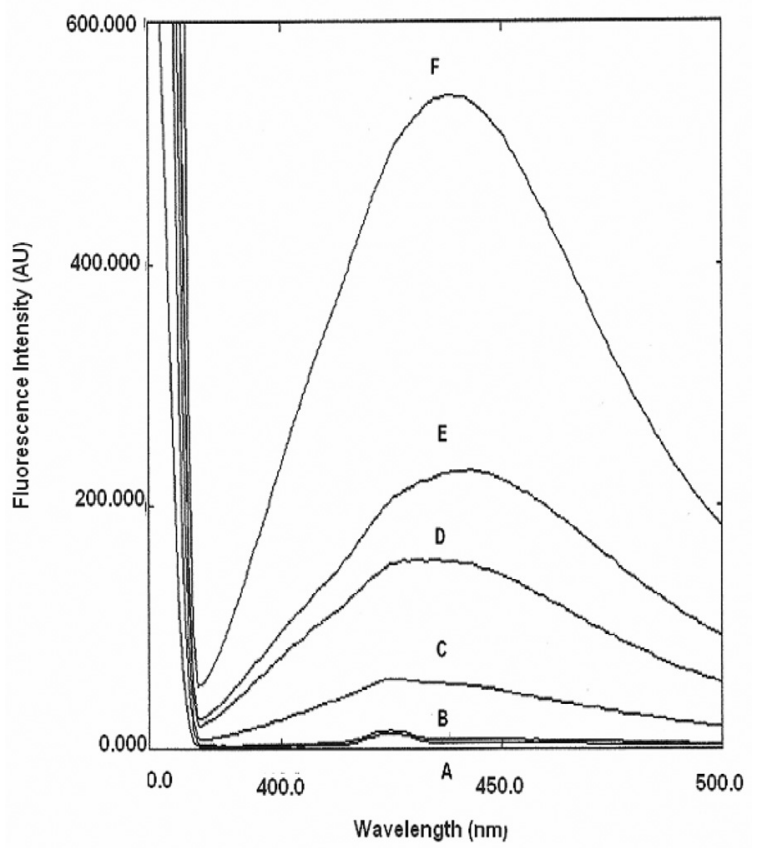

Fig. 2. Emission profile of buffer (A), $10 \mu \mathrm{g} / \mathrm{ml}$ DNA (B), DNA glycated for; 3 days $(\mathbf{C}), 7$ days $(\mathbf{D}), 10$ days $(\mathbf{E})$ and 14 days $(\mathbf{F})$. The fluorescence intensity increased with time.

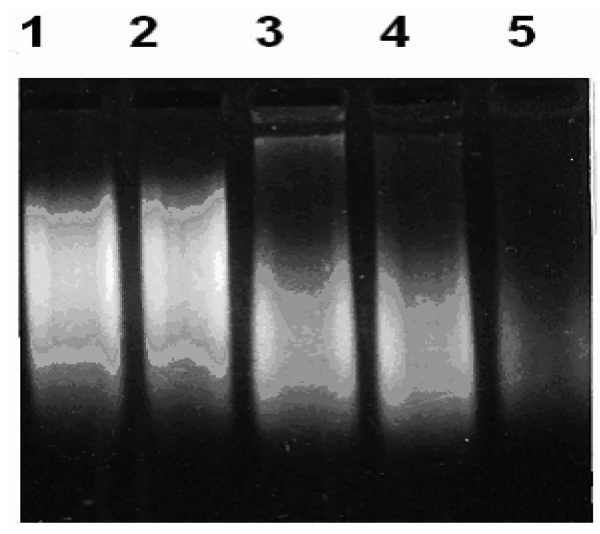

Fig. 3. Agarose gel electrophoresis of control DNA (lane 1). DNA glycated for $3,7,10$ and 14 days are represented by lanes $2-5$ respectively.

Autoantibodies in fifty five percent of diabetes sera (83/150) showed more binding with glycated-DNA compared to native DNA. Sera from healthy individuals included as control did not show significant binding with either of the coated antigens. The diabetes sera which showed high binding with glycated-DNA were subjected to inhibition ELISA to evaluate true interaction of autoantibodies in diabetes with glycatedDNA. Results of inhibition ELISA are given in Table 3.
Table 3

Inhibition ELISA of selected diabetic sera with native- and DNAAGEs (glycated- DNA) as inhibitors

\begin{tabular}{|c|c|c|}
\hline Serum no. & $\begin{array}{l}\text { Max. \% inhibition with } \\
\text { native DNA }\end{array}$ & $\begin{array}{c}\text { Max. \% inhibition with } \\
\text { DNA - AGEs }\end{array}$ \\
\hline 4 & 36 & 48 \\
\hline 16 & 54 & 70 \\
\hline 17 & 56 & 74 \\
\hline 19 & 40 & 56 \\
\hline 21 & 30 & 64 \\
\hline 25 & 38 & 52 \\
\hline 30 & 22 & 68 \\
\hline 37 & 36 & 50 \\
\hline 38 & 28 & 40 \\
\hline 40 & 34 & 50 \\
\hline 41 & 34 & 66 \\
\hline 42 & 34 & 63 \\
\hline 48 & 36 & 78 \\
\hline 51 & 38 & 57 \\
\hline 52 & 26 & 38 \\
\hline 53 & 38 & 64 \\
\hline 56 & 24 & 48 \\
\hline 57 & 32 & 62 \\
\hline 58 & 32 & 68 \\
\hline 59 & 30 & 54 \\
\hline 60 & 30 & 60 \\
\hline 62 & 34 & 50 \\
\hline 63 & 54 & 70 \\
\hline 64 & 42 & 84 \\
\hline 65 & 28 & 78 \\
\hline 77 & 26 & 45 \\
\hline 94 & 20 & 34 \\
\hline 134 & 40 & 68 \\
\hline 143 & 18 & 46 \\
\hline 150 & 30 & 59 \\
\hline
\end{tabular}

Note: The serum numbers in Table 3 correspond to serum number in Fig. 4

The data clearly indicates presence of autoantibodies against glycated-DNA in a sub-population of diabetes patients.

\subsection{Correlation between $H b A_{1 c}$ and anti-glycosylated-DNA autoantibodies}

Linear correlation analysis was performed using absorbance difference as dependent variable and HbA1c\%, nephropathy, neuropathy, blood pressure and lipids as independent variables (Table 4). It was found that the absorbance difference was significantly related to $\mathrm{HbA}_{1 c}(r=0.486, p<0.001)$, nephropathy $(r=$ $0.239, p<0.003)$, retinopathy $(r=0.165, p<0.05)$ and serum triglycerides and VLDL-cholesterol $(r=$ $0.186, p<0.001$ and $r=0.190, p<0.001$ respectively). 


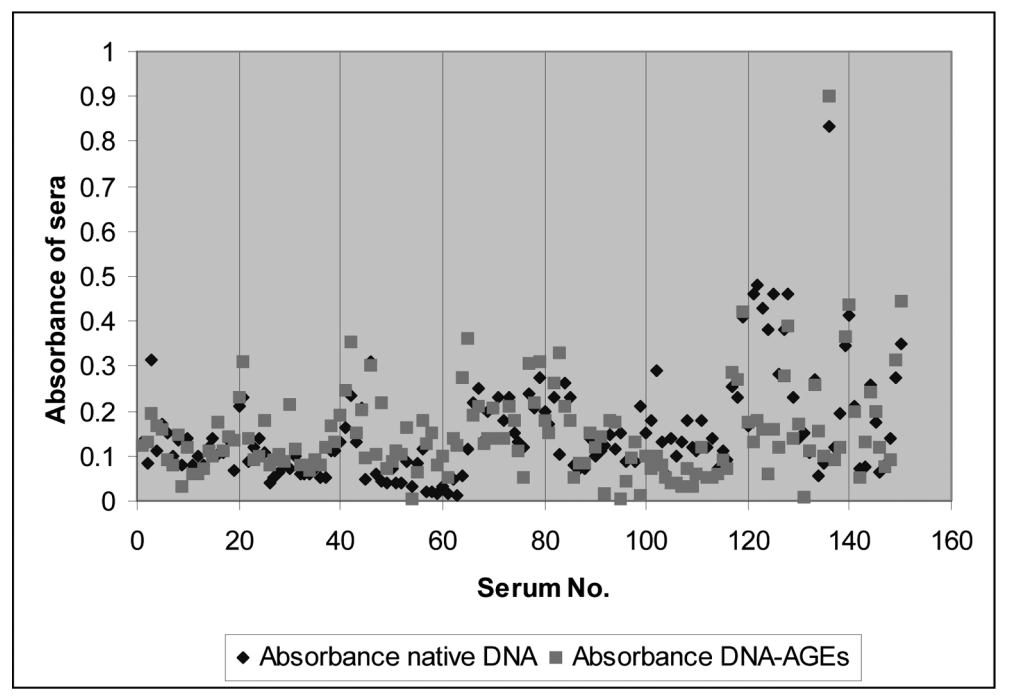

Fig. 4. Direct binding ELISA of diabetes sera (1:100 dilutions) on microtitre wells coated with native and DNA-AGEs (glycated-DNA).

Table 4

Linear correlation using absorbance difference as dependent variable in diabetic subjects, $(n=141)$

\begin{tabular}{lcccl}
\hline Variable & $\mathrm{r}$ & $\mathrm{r}^{2}$ & \multicolumn{1}{c}{$t$} & \multicolumn{1}{c}{$p$} \\
\hline \%HbA1c & 0.486 & 0.236 & 6.55 & $<0.001$ \\
Nephropathy & 0.239 & 0.057 & 2.90 & $<0.003$ \\
Neuropathy & 0.034 & 0.001 & 0.401 & $>0.05$ \\
Retinopathy & 0.165 & 0.027 & 0.027 & $<0.05$ \\
Triglycerides, mg\% & 0.186 & 0.034 & 2.230 & $<0.001$ \\
HDL, mg\% & 0.065 & 0.004 & 0.768 & $>0.05$ \\
LDL, mg\% & 0.013 & 0.001 & 0.153 & $>0.05$ \\
VLDL, mg\% & 0.190 & 0.036 & 2.282 & $<0.001$ \\
Systolic BP, mmHg & 0.108 & 0.011 & 1.280 & $>0.05$ \\
Diastolic BP, mmHg & 0.135 & 0.018 & 1.607 & $>0.05$ \\
\hline
\end{tabular}

\section{Discussion}

Our understanding of the relationship between glycemic control and the chronic complications of diabetes has been greatly enhanced by the results of several recent seminal intervention studies [14-16]. These studies demonstrated that microvascular complications are highly correlated with mean glycemic control, as measured by glycated hemoglobin $\left(\mathrm{HbA}_{1 c}\right)$, and that improvement in glycemic control results in reduction in all microvascular complications. In contrast, they failed to show a significant reduction in macrovascular complications with improved glycemic control, suggesting that macrovascular complications are the results of multiple metabolic abnormalities. A direct relationship between chronic hyperglycemia and microand macro-vascular complications in type 2 diabetes has been emphasised, over and again [28-30]. Persistent hyperglycemia can produce structural changes in long-lived macromolecules which may persist even after restoration of euglycemia [31].

In this study, glycated-DNA was prepared by incubating native DNA with glucose-6-phosphate (cellular metabolite of glucose). Generation of DNA-AGEs was confirmed by fluorescent studies. Recent studies have demonstrated that nucleobases can also be a target for non-enzymatic attack by reactive carbonyl compounds and that the presence of these nucleobase adducts may also play role in vivo [5]. In the present study, higher binding with glycosylated-DNA against native-DNA in diabetic patients with $\mathrm{HbA}_{1 c}$ of $9.8 \pm 3.3 \%$ compared to those with HbA1c of $7.7 \pm 1.7 \%(p<0.001)$ indicates the effects of DNA are marked in diabetes. The results are in agreement with earlier report [32], where the study has shown that like protein, nucleic acids can also undergo non-enzymatic modification by reducing sugars and produce spectral/ structural changes similar to those reported for non-enzymatic browning of proteins. The DNA glycation marker, N2-carboxyethyl2 '-deoxyguanosine, has been reported in kidney and aorta of diabetic and uremic patients [33].

In view of the immunogenic nature of AGEs, it may not be out of context to think that persistence of similar structures in vivo can initiate/propagate autoimmune response [13]. In the present study, the presence of antiDNA-AGEs autoantibodies in $55 \%$ of diabetic sera may be as a consequence of auto immune response against persistent DNA-AGEs in long term hyperglycemia. A significant correlation was also observed with $\mathrm{HbA}_{1 c}$ and absorbance different between DNA-AGEs and native DNA. Anti-DNA-AGEs autoantibodies were al- 
so correlated with diabetic retinopathy and nephropathy. It is quite possible that the apoptotic DNA might stay in the blood circulation of diabetic patients for a longer period and may undergo heavy glycation to generate DNA-AGEs in long term hyperglycemia. The AGEs of DNA nucleobases have receive little attention , perhaps due to the fact that adenine, guanine, cytosine and thymine do not dissolve under mild $\mathrm{pH}$ conditions. To maintain nucleobases in solution, alkaline pH conditions are necessary. Udayan et. al., 2006, evaluated non-enzymatic glycation of DNA nucleobases under alkaline $\mathrm{pH}$ [34] and demonstrated that N2carboxyethyldeoxyguanosine formed during the glycation of DNA in vitro causes increased depurification of DNA. Nucleotide glycation and related effects are expected to be most marked in diseases associated with the accumulation of glycating agents to high concentrations, diabetes and uremia [35]. It also suggests that increased formation of $\alpha$-oxoaldehydes in hyperglycemia and oxidative stress are associated with diabetes [36].

Findings from the present study indicated that DNAAGEs and autoantibodies against glycosylated DNA are correlated with $\mathrm{HbA}_{1 c}$ and microvascular complications like diabetic retinopathy and nephropathy and may serve as additional biomarkers for assessment of chronic glycemia. However, a large prospective multicentric study is required to establish usefulness of DNA-AGEs and its autoantibodies in the assessment of glycemic control and its correlation with microvascular complications in diabetic subjects.

\section{Acknowledgement}

Authors deeply appreciate the help extended by Dr. Kiran Dixit, Research Associate in the Department of Biochemistry, J.N. Medical College, in conducting the experiments. Authors declare that there is no conflict of interest.

\section{References}

[1] L.C. Maillard, Effects of amino acids on sugars: training malaniodines through methodical, Account Acad Sci $\mathbf{1 5 4}$ (1912), 66-68

[2] W.G. John and E.J. Lamb, The Maillard or browning reaction in diabetes, Eye 7 (1993), 230-237.

[3] D.S. Raj, D. Choudhury, T.C. Welbourne and M. Levi, Advanced glycation end products: a Nephrologist's perspective, Am J Kidney Dis 35 (2000), 365- 380.

[4] U. Dutta, M.A. Cohenford and J.A. Dain, Nonenzymatic glycation of DNA nucleosides with reducing sugars, Anal Biochem 343 (2005), 237-243.
[5] M.O. Lederer, F. Gerum and T. Severin, Cross-linking of proteins by Maillard processes: model reactions of D-glucose or methylglyoxal with butylamine and guanidine derivatives, Bioorg Med Chem 6 (1998), 993-1002.

[6] A. Bierhaus, M.A. Hofmann, R. Ziegler and P.P. Nawroth, AGE and their interaction with AGE receptors in vascular disease \& diabetes. 1. The AGE concept, Cardiovasc Res 37 (1998), 586-600

[7] J.L. Wautier and A.M. Schmidt, Protein glycation: a firm link to endothelial cell dysfunction, Circ Res 95 (2004), 233-238.

[8] M. Schneider, G. Thoss, C. Hubner-Parajaz, R. KientschEngel, P. Stahl and M. Pischetrieder, Determination of glycated nucleobases in human urine by a new monoclonal antibody specific for N2-carboxyethyl-2'-deoxyguanosine, Chem Res Toxicol 17 (2004), 1385-1390.

[9] M. Schneider, A. Georgescu, C. Bidmon, M. Tutsch, E.H. Fleischmann, D. Popov and M. Pischetrieder, Detection of DNA-bound advanced glycation end-products by immunoaffinity chromatography coupled to HPLC-diode array detection, Mol Nutr Food Res 50 (2006), 424-429.

[10] N. Murata-Kamiya, H. Kamiya, H. Kaji and H. Kasai, Glyoxal, a major product of DNA oxidation, induces mutations at G:C sites on a shuttle vector plasmid replicated in mammalian cells, Nucleic Acids Res 25 (1997), 1897-1902.

[11] N. Murata-Kamiya, H. Kamiya, H. Kaji and H. Kasai, Methylglyoxal induces $\mathrm{G}: \mathrm{C}$ to $\mathrm{C}: \mathrm{G}$ and $\mathrm{G}: \mathrm{C}$ to $\mathrm{T}: \mathrm{A}$ transversions in the supF gene on a shuttle vector plasmid replicated in mammalian cells, Mutat Res 468 (2000), 173-182.

[12] S. Horiuchi, N. Araki and Y. Morino, Immunochemical approach to characterize advanced glycation end products of the Maillard reaction. Evidence for the presence of a common structure, J Biol Chem 266 (1991), 7329-7332.

[13] Z. Turk, S. Ljubic, N. Turk and B. Benko, Detection of autoantibodies against advanced glycation endproducts and AGEimmune complexes in serum of patients with diabetes mellitus, Clinica Chimica Acta 303(1-2) (2001), 105-115.

[14] The Diabetes Control and Complications Trial Research Group: The effect of intensive treatment of diabetes on the development and progression of long-term complications in insulin-dependent diabetes mellitus, NEngl J Med329 (1993), 977-986.

[15] United Kingdom Prospective Diabetes Study Group: Intensive blood-glucose control with sulfonylureas or insulin compared with conventional treatment and risk of complications in patients with type 2 diabetes (UKPDS33), Lancet 352 (1998), 837-853.

[16] Y. Ohkubo, H. Kishikawa, E. Araki, T. Mirata, S. Isami, S. Motoyoshi, Y. Kojima, H. Furuyoshi and M. Shichiri, Intensive insulin therapy prevents the progression of diabetic microvascular complications in Japanese patients with noninsulin-dependent diabetes mellitus: a randomized prospective 6-years study, Diabetes Res Clin Pract 28 (1995), 103117.

[17] K. Dahl-Jørgensen, Biochemical Markers of Diabetic Microangiopathy Past, Present and Future, Hormone Res 50 (1998), 12-16.

[18] D.R. Sell, A. Lapolla, P. Odetti, J. Fogarty and V.M. Monnier, Pentosidine formation in skin correlates with severity of complications in individuals with long-standing IDDM, Diabetes 41 (1992), 1286-1292.

[19] D.R. McCance, D.G. Dyer and J.A. Dunn, Maillard reaction products and their relation to complications in insulin dependent diabetes mellitus, J Clin Invest 91 (1993), 2470-2478. 
[20] H. Vlassara, L.J. Striker, G.S. Teichber, H. Fuh, Y.M. Li and M. Steffes, Advanced glycation endproducts induce glomerular sclerosis and albuminuria in normal rats, Proc Natl Acad Sci (USA) 91 (1994), 11704-11708.

[21] P.J. Beisswenger, Z. Makita, T.J. Curphey, L.L. Moore, S. Jean, T. Brinck-Johnsen, R. Bucala and H. Vlassara, Formation of immunochemical advanced glycation endproducts precedes and correlates with early manifestations of renal and retinal disease in diabetes, Diabetes 44 (1995), 824-829.

[22] B. Levi and M.J. Werman, Fructose and related phosphate derivatives impose DNA damage and apoptosis in L5178Y mouse lymphoma cells, J Nutr Biochem 14 (2003), 49-60.

[23] B. Sengupta and J. Swenson, Properties of normal and glycated human hemoglobin in presence and absence of antioxidant, Biochem Biophys Res Commun 334 (2005), 954-959.

[24] M. Sakai, M. Oimomi and M. Kasuga, Experimental studies on the role of fructose in the development of diabetic complications, Kobe J Med Sci 48 (2002), 125-136.

[25] R.J. Smith, R.J. Koenig, A. Binnerts, S. Soeldner and T.T. Aoki, Regulation of haemoglobin $\mathrm{A}_{1 c}$ formation in human erythrocytes in vitro, J Clin Invest 69 (1982), 1164-1168.

[26] R. Ali and K. Alam, Methods in Molecular Biology: Oxidative stress biomarkers and antioxidant protocols, in: Humana Press, New Jersey, (Vol. 186) (1st edition), D. Armstrong, Editor, 2002, pp. 171-181.

[27] M. Roumyana, N. Toshimitsu, H. Yordan, S. Angelina and I. Ivan, Evidence for non-enzymatic glycosylation of Escherichia coli chromosomal DNA, Mol Microbiol 55(6) (2005), 1801-1811.

[28] N. Kaiser, S. Sasson, E.P. Feener, N. Boukobza-Vardi, S. Higashi, D.E. Moller, S. Davidheiser, R.J. Przybylski and G.L. King, Differential regulation of glucose transport and transporters by glucose in vascular endothelial and smooth muscle cells, Diabetes 42 (1993), 80-89.
[29] J. Kuusisto, L. Mykkanen, K. Pyorala and M. Laakso, NIDDM and its metabolic control predict heart disease in elderly subjects, Diabetes 43 (1994), 960-967.

[30] Y. Ohkubo, H. Kishikawa, E. Araki, T. Miyata, S. Isami, S. Motoyoshi, Y. Kojima, N. Furuyoshi and M. Shichiri, Intensive insulin therapy prevents the progression of diabetic microvascular complications in Japanese patients with noninsulin-dependent diabetes mellitus: Randomized prospective 6-year study, Diabetes Res Clin Pract 28 (1995), 103-117.

[31] C.W. Heilig, L.A. Concepcion, B.L. Riser, S.O. Freyta, M. Zhu and P. Cortes, Over expression of glucose transporters in rat mesangial cells cultured in a normal glucose milieu mimics the diabetic phenotype, J Clin Invest 96 (1995), 1802-1814.

[32] R. Bucala, M. Peter and C. Anthony, Modification of DNA by reducing sugars: A possible mechanism for nucleic acid aging and age-related dysfunction in gene expression, Biochemistry 81 (1984), 105-109.

[33] H. Li, S. Nakmura, S. Miyazaki, T. Morita, M. Suzuki, M. Pischetsrieder and T Niwa, Carboxyethyl-2'-deoxyguanosine, a DNA glycation marked, in kidneys and aortas of diabetic and uremic patients, Kidney Int 69 (2006), 388-392.

[34] U. Dutta, A. Menashi, C. Ford, G. Madhumita and J.A. Dain, In-vitro non-enzymatic glycation of DNA nucleobase: an evaluation of advanced glycation end products under alkaline $\mathrm{pH}$, Anal Bioanal Chem 386 (2006), 1633-1640.

[35] P.J. Thornally, Pharmacology of methylation: formation, modification of proteins and nucleic acids, and enzymatic detoxification- a role in pathogenesis and antiproliferative chemotherapy, Gen Pharmacol 27 (1997), 565-573.

[36] T. Nishikawa, T. Edelstein, D. Liang, S. Yamagishi, T. Matsumura, Y. Kaneda, M.A. Yorek, D. Beede, P.J. Oates and H.P. Hammes, normalizing mitochondrial superoxide production blocks three pathways of hyperglycemia damage, Nature $\mathbf{4 0 4}$ (2000), 787-790. 


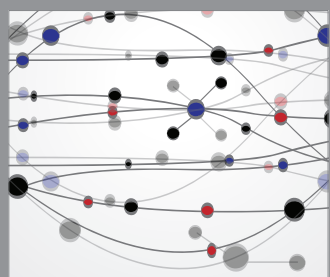

The Scientific World Journal
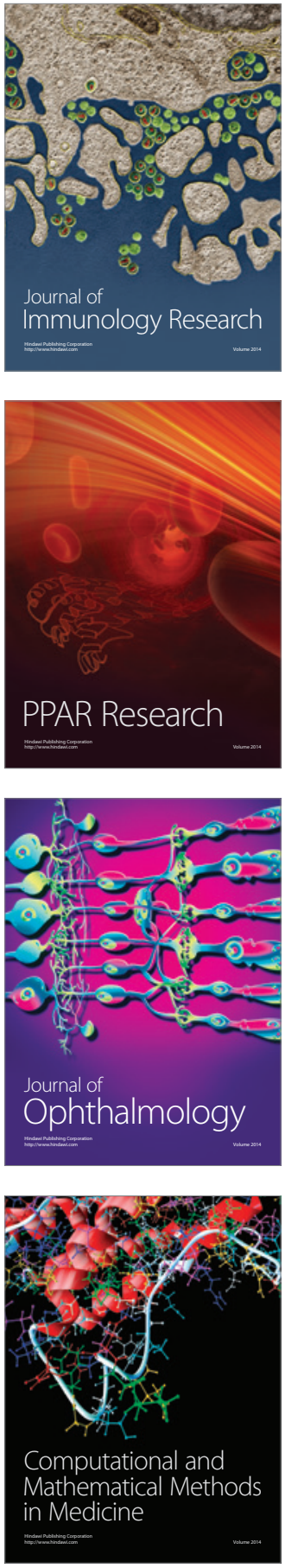

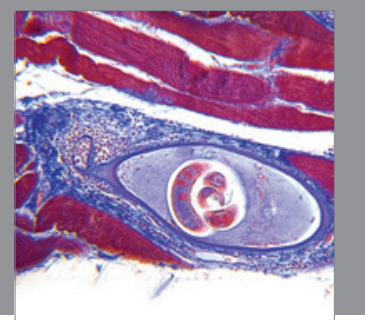

Gastroenterology

Research and Practice
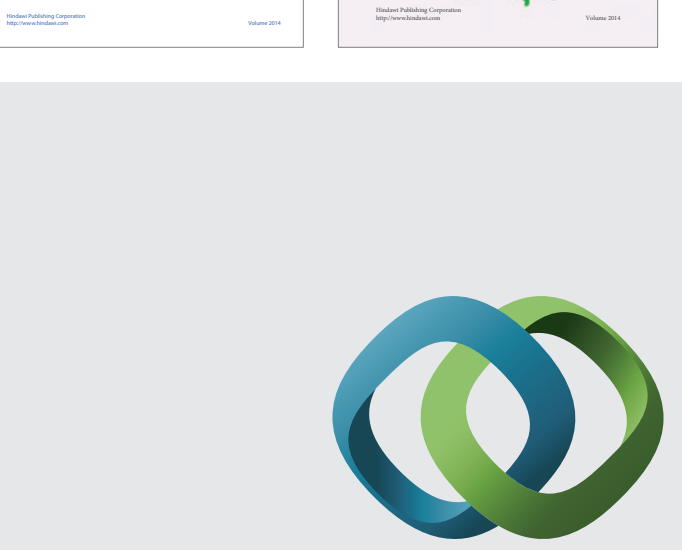

\section{Hindawi}

Submit your manuscripts at

http://www.hindawi.com
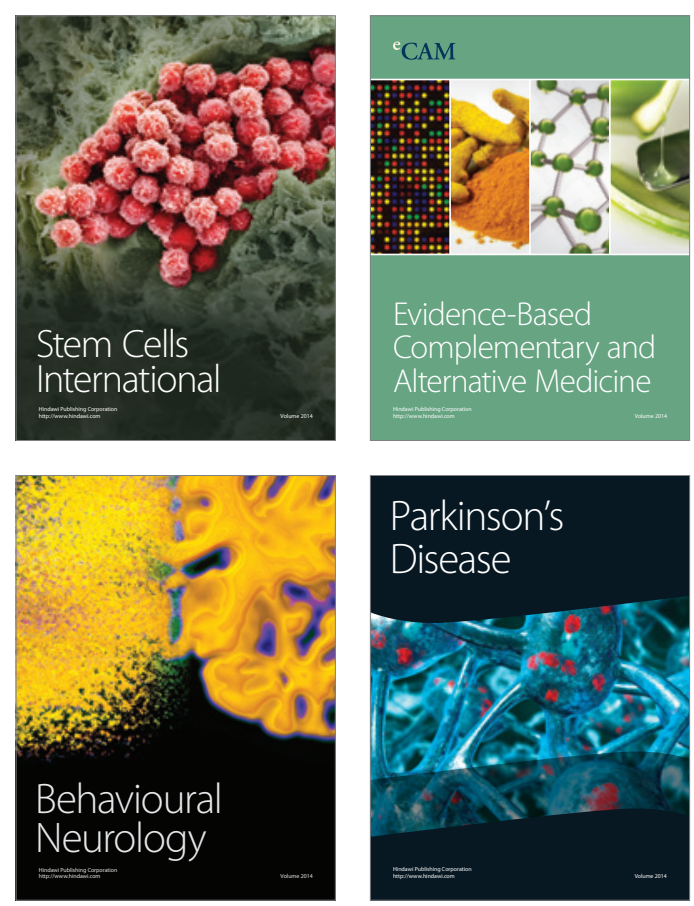

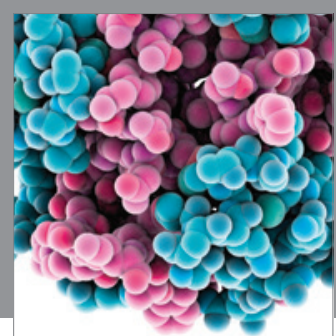

Journal of
Diabetes Research

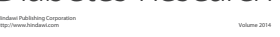

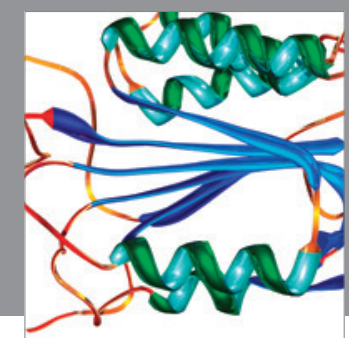

Disease Markers
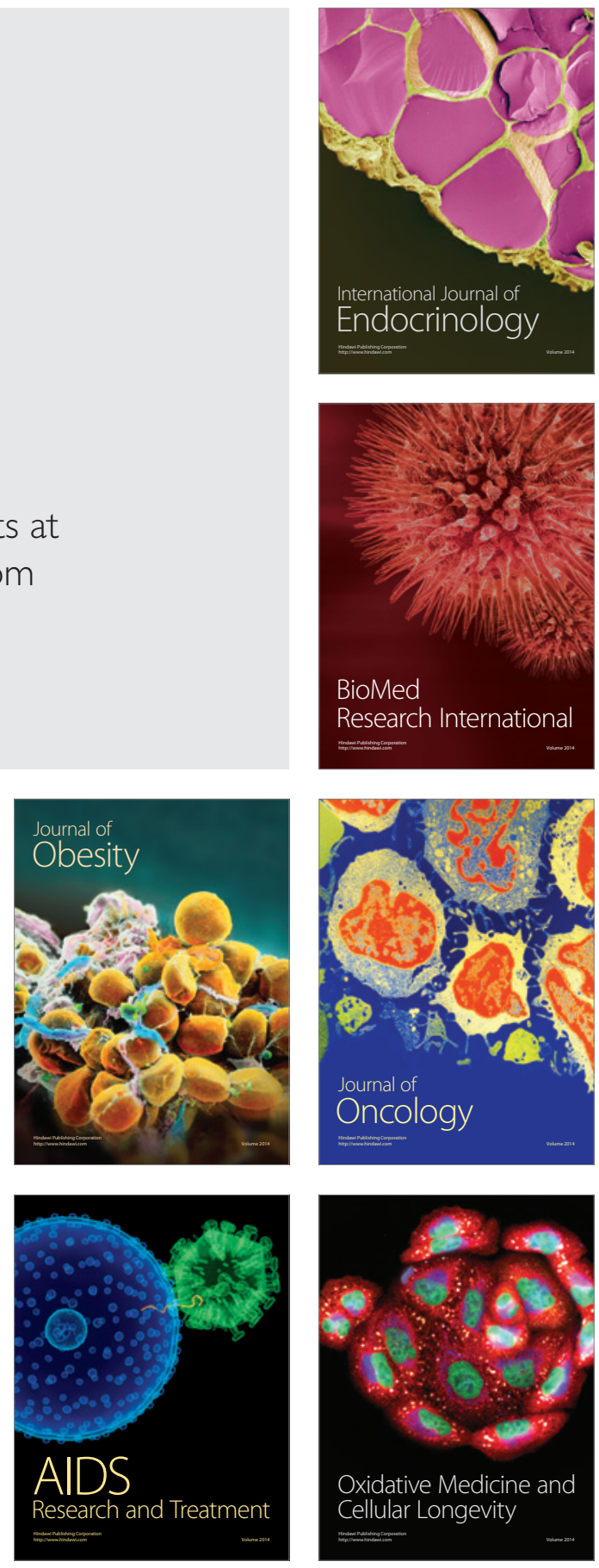